\title{
SEBARAN PANJANG (FL), TINGKAT KEMATANGAN GONAD DAN KOMPOSISI MAKANAN IKAN KEMBUNG (Rastrelliger brachyosoma) PADA BULAN NOPEMBER 2006 DI PERAIRAN PANTAI KALIMANTAN BARAT
}

\author{
Tuti Hariati'1), Achmad Zamroni'1), dan Rahmat Setiawan ${ }^{2)}$ \\ 1) Peneliti pada Balai Riset Perikanan Laut, Muara Baru-Jakarta \\ 2) Teknisi pada Balai Riset Perikanan Laut, Muara Baru-Jakarta \\ Teregistrasi I tanggal: 14 Oktober 2008; Diterima setelah perbaikan tanggal: 19 Januari 2009; \\ Disetujui terbit tanggal: 23 Pebruari 2009
}

\begin{abstract}
ABSTRAK
Informasi keadaan sumber daya ikan kembung (Rastrelliger brachyosoma) di perairan pantai Kalimantan Barat perlu untuk diperkaya. Dengan indikasi semakin turunnya hasil tangkapan ikan kembung sampai tahun 2005, pada bulan Nopember 2006 dilakukan pengumpulan data dan pengamatan aspek biologi ikan kembung. Hasil pengamatan memperlihatkan bahwa sebaran panjang ikan kembung pada bulan Nopember 2006 sesuai dengan sebaran panjang pada bulan Januari 1993. Komposisi tingkat kematangan gonad ikan kembung pada bulan Nopember 2006 sesuai dengan musim dan tingkat kematangan gonad pada bulan Januari 1993. Jenis makanan didominansi plankton nabati terutama Chaetoceros sp. dan Coscinodiscus sp., sama dengan jenis makanan ikan kembung di perairan lain. Diperlukan kajian yang rutin paling tidak 1 tahun terhadap sumber daya perikanan ikan kembung di perairan pantai wilayah Kalimantan Barat, untuk kelestarian stok dan usaha penangkapannya.
\end{abstract}

KATAKUNCI: ikan kembung (Rastrelliger brachyosoma), perairan barat Kalimantan

\section{PENDAHULUAN}

Sekitar tahun 1950-1990-an Propinsi Kalimantan Barat terkenal dengan ikan kembung (Rastrelliger brachyosoma) yang segar maupun yang diolah menjadi peda (Merta, 1993) sebagai salah satu jenis ikan yang menjadi kegemaran masyarakat dalam memenuhi kebutuhan gizi secara murah. Kedua jenis produk tersebut merupakan komoditas ekspor untuk Serawak (segar) dan Singapura (peda). Golongan ikan kembung yang didaratkan di Kalimantan Barat paling sedikit terdiri dari 2 spesies yaitu ikan kembung penghuni perairan pantai (neritic), dan ikan banyar (Rastrelliger kanagurta) hidup di perairan yang lebih ke tengah (offshore) dengan kadar garam paling rendah 32 per mil (Longhurst \& Pauly, 1987).

Total produksi ikan kembung dan banyar tahun 1991 di Propinsi Kalimantan Barat mencapai 4.000 ton atau $6,7 \%$ dari total produksi perikanan laut (Merta, 1994) dengan produksi ikan kembung dan banyar masing-masing 3.500 dan 5.000 ton. Pada tahun 1996 produksi total kedua jenis ikan kembung tersebut mencapai puncak 13.000 ton (12.600 ton di antaranya ikan kembung), kemudian turun pada tahun 2005 sampai 1.800 ton dengan produksi ikan kembung 1.600 ton (Anonimus, 1992-2006).

Ikan kembung ditangkap oleh para nelayan sepanjang pantai Kalimantan Barat dengan pusat- pusat pendaratan dari selatan (Tanjung Satai, Kabupaten Ketapang), ke arah utara Mempawah, Sei Bakau di Kabupaten Pontianak, dan Sungai Duri di Kabupaten Bengkayang. Alat tangkap di wilayah Ketapang terutama jaring insang lingkar dan di Pontianak jaring insang tetap. Dari tahun 1994-2005 produksi ikan kembung yang tinggi berasal dari hasil tangkapan jaring insang lingkar $(71 \%)$ dan jaring insang tetap (10\%). Dan 19\% sisanya berasal dari jenis-jenis alat tangkap lain yaitu jaring insang hanyut, jermal, dan sero.

Menurut De Beaufort \& Chapman (1951), Rastrelliger brachyosoma (Gambar 1) merupakan salah satu dari 3 spesies ikan kembung dari genus Rastrelliger, 2 spesies lain adalah Rastrelliger kanagurta dan Rastrelliger neglectus. Genus Rastrelliger termasuk ke dalam Tribus Scombrini, Sub family Scombrinae dan family Scombridae (Collette \& Nauen, 1983). Sedangkan berdasarkan pada analisis morfometrik terhadap contoh ikan kembung di perairan Laut Jawa dan sekitarnya yang tertangkap di Jakarta dan Tanjung Satai (Kalimantan Barat), Sudjastani (1976) menyimpulkan bahwa di perairan tersebut hanya ada 2 spesies yaitu Rastrelliger brachyosoma dan Rastrelliger kanagurta. Sedangkan Rastrelliger neglectus diduga sebagai sinonim dari Rastrelliger brachyosoma. 


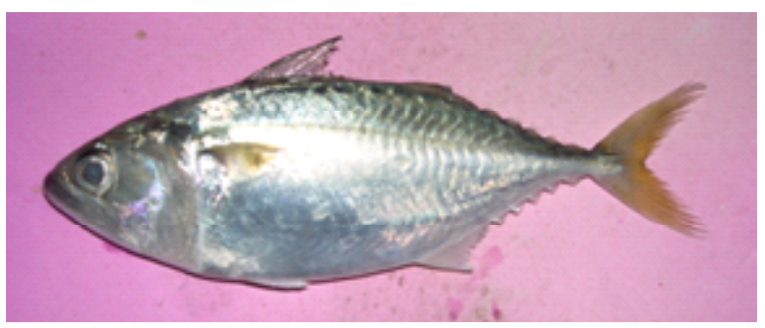

Gambar 1. Ikan kembung perempuan (Rastrelliger brachyosoma).

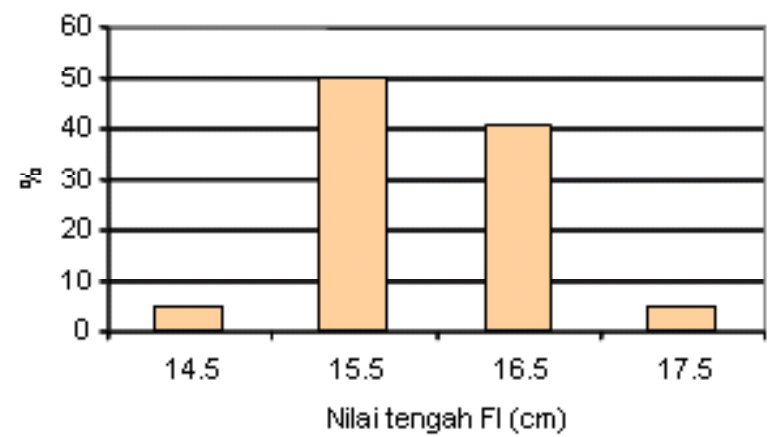

Gambar 1a. Sebaran panjang ikan kembung dari perairan Ketapang, Kalimantan Barat bulan Nopember 2006.

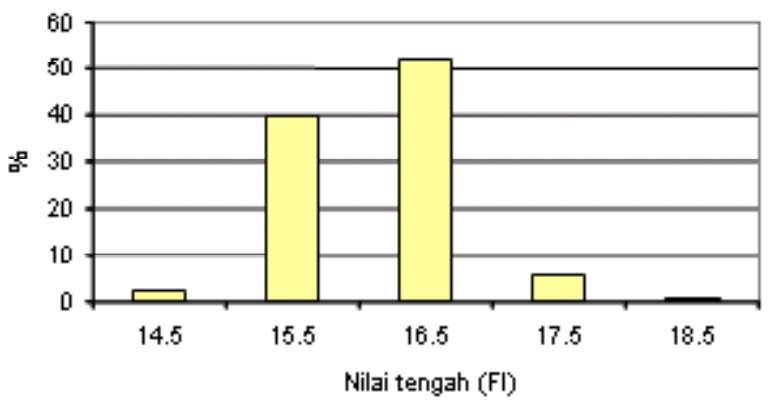

Gambar 1b. Sebaran panjang ikan kembung dari perairan Ketapang, Kalimantan Barat bulan Januari 1993.

Sumber: Merta (1994)

Ciri khas Rastrelliger brachyosoma antara lain badan paling tinggi di antara kedua spesies lain, mempunyai intestin yang sangat panjang. Maxilla diliput oleh tulang lacrimal yang meluas sampai ke ujung maxilla. Panjang maksimal ikan kembung 34,5 cm FL, yang umum tertangkap dari $15-20 \mathrm{~cm}$ FL, panjang pertama kali matang gonad $\left(I_{m}\right)$ sekitar 16 $\mathrm{cm}$. Rastrelliger brachyosoma hidup di perairan dengan suhu permukaan $20-30^{\circ} \mathrm{C}$. Di daerah estuaria, spesies ini toleran terhadap penurunan kadar garam. Makanan terdiri atas plankton dengan komponen plankton nabati merupakan bagian yang besar (Anonimus, 2001).

Pengkajian stok ikan kembung di perairan pantai Kalimantan Barat dilakukan oleh Mertha pada tahun 1993, menggunakan data produksi ikan kembung dan jumlah alat tangkap yang dengan setara jaring lingkar tahun 1982-1991. Hasil analisis data dengan model produksi surplus menunjukkan tingkat pengusahaan ikan kembung di pantai Kalimantan Barat saat itu mencapai 77\%. Selanjutnya menurut Merta (1994) 
pengembangan perikanan ikan kembung tersebut dapat dilakukan secara hati-hati dan bertahap ke arah lepas pantai di mana status perkembangan saat ini setelah berjalan selama 15 tahun belum dapat diperoleh.

Saat ini informasi stok sumber daya ikan kembung di perairan pantai Kalimantan Barat yang berbasis hasil penelitian belum memadai. Sehubungan dengan indikasi menurunnya hasil tangkapan ikan kembung dari tahun 1997-2005, maka pada bulan Nopember 2006 dilakukan pengumpulan data dan pengamatan aspek biologi ikan kembung dengan tujuan sebagai salah satu upaya memperbaharui data perikanan kembung di kawasan ini.

\section{ASPEK BIOLOGI}

\section{Sebaran Panjang Ikan Kembung}

Dari pengambilan contoh ikan kembung yang tertangkap dari perairan Ketapang pada bulan Nopember 2006 telah diperoleh sebaran panjang ikan antara 14-18 cm (FL) dengan modus pada $15,5 \mathrm{~cm}$ (Gambar 1a) dan panjang rata-rata 15,7 cm.

Dibandingkan dengan pada bulan Januari 1993 (Gambar 1b) di perairan yang sama diperoleh sebaran $14-19 \mathrm{~cm}(\mathrm{FL})$ dengan modus $16,5 \mathrm{~cm}$ dan panjang rata-rata 16,1 cm (Gambar 1b), tampaknya panjang contoh ikan yang ditemukan pada bulan Nopember 2006 lebih kecil. Ini belum berarti bahwa ukuran ikan kembung pada tahun 2006 sudah mengecil dari tahun 1993, mengingat ukuran ikan dalam tiap musim berubah menurut tingkatan pertumbuhannya.

Setiap tahun pada musim pemijahan yang menurut Merta (1994) berlangsung antara bulan April dan Oktober, ikan kembung dewasa melakukan migrasi ke daerah pemijahan yang belum diketahui secara rinci. Jika dilihat dari urutan bulan, maka kesesuaian kisaran dan modus panjang ikan kembung pada bulan Januari lebih besar daripada bulan Nopember, sedangkan sebagai informasi diketahui bahwa dari hasil pengukuran tiap bulan pada tahun 1971-1972 Sudjastani (1974) memperoleh panjang maksimum $\left(\mathrm{L}_{\max }\right)$ ikan kembung 20,4 cm (FL).

\section{Biologi Reproduksi}

Pengamatan jenis kelamin terhadap 67 spesimen contoh ikan kembung, 22 spesimen di antaranya berjenis kelamin betina, sedangkan 45 lain terdiri atas jenis jantan, sehingga perbandingan jumlah ikan betina terhadap jantan $1: 2$, berarti jumlah ikan jantan lebih banyak dari ikan betina.
Dari pengamatan tingkat kematangan gonad, diperoleh komposisi (Gambar 2a), yang memperlihatkan bahwa sebagian besar dari gonad ikan betina berada dalam kondisi perkembangan awal atau immature (tingkat kematangan gonad I dan II) dengan didominansi tingkat kematangan gonad I. Terdapat juga ikan betina yang mulai matang atau maturing (tingkat kematangan gonad III) dalam persentase yang rendah. Jenis betina tingkat kematangan gonad IV, yang sedang dalam proses pematangan lebih lanjut dan yang sudah siap memijah (mature), belum ditemukan. Jenis betina yang sudah melakukan pemijahan (spent) (tingkat kematangan gonad V) ditemukan dalam contoh. Ini menunjukkan bahwa pada bulan Nopember 2006, walaupun sudah memasuki awal musim penangkapan atau penambahan baru, ada ikan kembung yang belum selesai atau hampir selesai memijah, karena akhir musim pemijahan yaitu bulan Oktober (Sudjastani, 1974; Merta, 1994), belum lama berlalu.

Menurut Merta (1994); Sudjastani (1974), musim penangkapan ikan kembung di perairan pantai Kalimantan Barat khususnya di Kabupaten Ketapang berlangsung dari bulan Oktober-April, sedangkan bulan dari Mei-September atau Oktober ikan kembung tidak tertangkap, diduga pergi ke perairan lain untuk melakukan pemijahan.

Dari hasil pengamatan Merta (1994) pada bulan Januari 1993 (Gambar 2b) diperoleh ikan betina yang juga seperti pada bulan Nopember 2006, sebagian besar terdiri atas ikan yang immature. Perbedaan terletak pada persentase tingkat kematangan gonad Il yang lebih dominan dari tingkat kematangan gonad I. Persentase ikan betina yang mulai matang (tingkat kematangan gonad III) pada bulan Januari 1993 sedikit lebih besar daripada bulan Nopember 2006. Ikan betina yang matang (tingkat kematangan gonad IV) belum ada (Gambar 2b), yang sudah memijah (tingkat kematangan gonad $\mathrm{V}$, spent) juga tidak ada, karena belum sampai musim pemijahan. Jadi sebaran tingkat kematangan gonad pada bulan Nopember 2006 menunjukkan kondisi perkembangan tingkat kematangan gonad yang awal ditandai dengan ada sisa ikan betina yang sedang dalam proses pemijahan. Pada bulan Januari 1993 komposisi tingkat kematangan gonad telah lebih berkembang karena dari yang semula pada tingkat kematangan gonad I sudah berubah menjadi tingkat kematangan gonad II.

\section{Jenis Makanan}

Dengan mengacu pada kunci identifikasi plankton (Yamaji, 1976), organisme makanan yang terdapat di dalam perut ikan kembung pada umumnya terdiri atas 


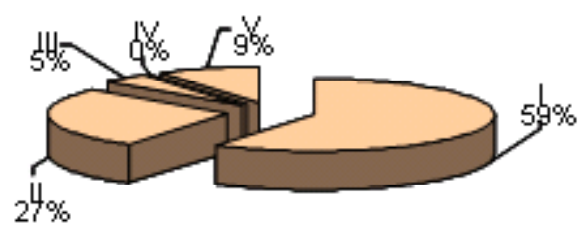

Gambar 2a. Komposisi tingkat kematangan gonad ikan kembung dari perairan Tanjung Satai, bulan Nopember 2006.

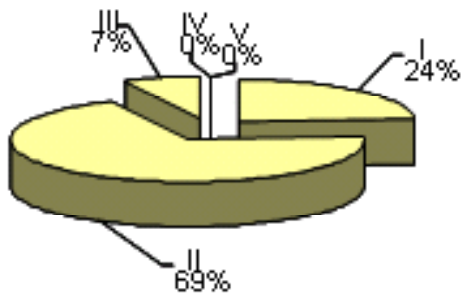

Gambar 2b. Komposisi tingkat kematangan gonad ikan kembung dari perairan Tanjung Satai, bulan Januari 1993.

Sumber: Merta (1994)

Tabel 1. Komposisi makanan ikan kembung dari perairan pantai Tanjung Satai, Kalimantan Barat, bulan Nopember 2006

\begin{tabular}{|c|c|c|c|c|c|c|}
\hline \multicolumn{2}{|c|}{ Plankton nabati } & \multirow{2}{*}{$\%$} & \multicolumn{3}{|c|}{ Plankton hewani } & \multirow{2}{*}{$\%$} \\
\hline Kelas & Genus & & & Kelas & Genus & \\
\hline \multirow[t]{23}{*}{ Bacillariophyceae } & Bacteriastrum sp. & 0,60 & & Actinopoda & Achantometron sp. & 0,16 \\
\hline & Biddulphia sp. & 3,65 & & Chaetognatha & Sagitta sp. & 0,15 \\
\hline & Chaetoceros sp. & 29,32 & & Crustaceae & Acartia sp. & 2,85 \\
\hline & Cocconeis sp. & 0,05 & & & Balanus sp. & 0,11 \\
\hline & Climacodium sp. & 0,15 & & & Calanus sp. & 0,75 \\
\hline & Coscinodiscus sp. & 13,59 & & & Corycaeus sp. & 0,31 \\
\hline & Diploneis sp. & 0,35 & & & Evadne sp. & 0,17 \\
\hline & Eucampia sp. & 0,15 & & & Microsetella sp. & 0,46 \\
\hline & Fragillaria sp. & 0,10 & & & Oithona sp. & 1.01 \\
\hline & Hemialus sp. & 2,80 & & & Oncaea sp. & 0,52 \\
\hline & Minidiscus sp. & 0,35 & & & Pontella sp. & 0,11 \\
\hline & Navicula sp. & 0,05 & & & Porvocalans sp. & 0,56 \\
\hline & Nitzschia sp. & 6,69 & & Mollusca & Limacina sp. & 0,55 \\
\hline & Planktoniella sp. & 0,05 & & Rhizopoda & Globorotalia sp. & 0,09 \\
\hline & Pleurosigma sp. & 2,35 & & Spirotricha & Codonellopsis sp. & 1,30 \\
\hline & Rhizosolenia sp. & 5,19 & & & Parafavella sp. & 0,11 \\
\hline & Stephanophyxis sp. & 0,25 & & & Tintinnopsis sp. & 3,11 \\
\hline & Streptotheca sp. & 0,05 & & Urochordata & Oikopleura sp. & 0,14 \\
\hline & Surirella sp. & 0,05 & & & & \\
\hline & Thalassionema sp. & 7,14 & Larva & & & \\
\hline & Thalassiosira sp. & 6,09 & & Mollusca & Veliger Anadara sp. & 0,19 \\
\hline & Thalassiothrix sp. & 1,4 & & Crustaceae & Sacculina sp. & 0,05 \\
\hline & Triceratium sp. & 0,15 & & & Nauplius & 0,95 \\
\hline Cyanophyceae & Trichodesmium sp. & 0,05 & & & Zoea & 0,14 \\
\hline \multirow[t]{8}{*}{ Dinophyceae } & Ceratium sp. & 0,20 & & & Mysis & 0,14 \\
\hline & Dictyocha sp. & 0,30 & & Polychaeta & & 0,09 \\
\hline & Dinophysis sp. & 1,45 & Tidak utuh & & Sisik ikan & 1,65 \\
\hline & Prorocentrum sp. & 0,05 & & & kepiting & 0,36 \\
\hline & Protoperidinium sp. & 0,30 & & & & \\
\hline & Pyrocystis sp. & 0,45 & & & & \\
\hline & Pyrophacus sp. & 0,65 & & & & \\
\hline & Total & & & & Total & 100.00 \\
\hline
\end{tabular}


jenis-jenis plankton nabati dan plankton hewani (Tabel 1).

Tabel 1 sebagian besar dari plankton nabati makanan ikan kembung dari perairan Tanjung Satai, Kabupaten Ketapang terdiri atas golongan Diatome dan Dinoflagellata, yang termasuk pada 3 kelas, yaitu Bacillariophyceae (Diatomae, 24 genus), Cyanophycea (1 genus), dan Dinophyceae (Dinoflagellata, 7 genus). Plankton hewani terdiri atas 7 kelas yaitu Actinopoda (1 genus), Chaetognatha (1 genus), Crustacea (12 genus), Mollusca (1 genus), Rhyzopoda (1 genus), Spyrotricha (3 genus), dan Urochordata (1 genus). Terdapat juga plankton hewani yang termasuk meroplankton seperti fase larva veliger dari mollusca, zoea, mysis, dan nauplius dari crustacea, serta larva Polychaeta. Organ yang tidak utuh terdapat dalam bentuk sisik ikan dan bagian tubuh dari kepiting.

Tabel 1 juga terlihat bahwa dari golongan Diatomae kelas Bacillariophyceae, di antara 24 genus terdapat 2 genus paling tinggi persentasenya yaitu Chaetoceros dan Coscinodiscus. Kedua genus plankton nabati tersebut sangat umum terdapat pada setiap perairan di wilayah Indonesia.

Tampak bahwa plankton nabati menempati $80 \%$ (makanan utama) dari makanan ikan kembung dari Tanjung Satai, sedangkan sisanya adalah plankton hewani dan jasad tidak utuh. Sebagai pemakan organisme nabati dapat dilihat juga dari intestin yang sangat panjang, menurut Biushing (1994) mencapai 3,4 kali panjang standar tubuh ikan kembung tersebut, dan menurut Collette \& Nauen (1983) mencapai 3,23,6 kali panjang cagak (FL).

Menurut Longhurts \& Pauly (1987) ikan dari genus Rastrelliger mempunyai kemampuan memanfaatkan sejumlah besar jenis makanan, yang meliputi jenisjenis alga hijau yang mikroskopis, copepoda, dan jenis plankton lain termasuk medusa dari ubur-ubur, juga larva udang dan juvenil ikan. Rastrelliger brachyosoma mengkonsumsi jenis makanan yang lebih kecil daripada makanan spesies lain seperti Rastrelliger kanagurta, yang terdiri atas macroplankton, dalam hal ini adalah plankton hewani.

\section{KESIMPULAN DAN SARAN}

\section{Kesimpulan}

1. Sebaran panjang ikan kembung pada bulan Nopember 2006 antara 14 dan $18 \mathrm{~cm}$ (FL) dengan modus pada $15,5 \mathrm{~cm}$ dan panjang rata-rata 15,7 $\mathrm{cm}$.
2. Komposisi gonad ikan betina sebagian besar belum matang gonad (59\% tingkat kematangan gonad I dan $27 \%$ tingkat kematangan gonad II), sisanya terdiri atas 5\% tingkat kematangan gonad III (mulai matang) dan 9\% tingkat kematangan gonad V (sudah memijah). Gonad yang matang (tingkat kematangan gonad IV) belum ditemukan karena belum sampai musim pemijahan.

3. Jenis makanan ikan kembung didominansi plankton nabati (Diatomae) dari genus Chaetoceros dan Coscinodiscus, di samping plankton hewani.

\section{Saran}

Diperlukan kajian yang rutin paling tidak selama satu tahun, mengenai aspek biologi dan sumber daya perikanan kembung di perairan pantai wilayah Kalimantan Barat, untuk mendapatkan siklus perkembangan ukuran dan kematangan gonad ikan betina, dalam rangka memelihara kelestarian stok dan usaha penangkapannya.

\section{PERSANTUNAN}

Kegiatan dari hasil riset perubahan upaya dan hasil tangkapan ikan pelagis kecil di Laut Jawa, Selat Makassar, dan Laut Cina Selatan, T. A. 2005 dan 2006 di Balai Riset Perikanan Laut-Muara Baru, Jakarta.

\section{DAFTAR PUSTAKA}

Anonimus. 1992-2006. Statistik Perikanan Propinsi Kalimantan Barat Tahun 1991-2005. Dinas Kelautan dan Perikanan Propinsi Kalimantan Barat.

Anonimus. 2001. The Living Marine Resources of the Western Central Pacific. Vol. 6. Bony Fishes Part 4 (Labridae to Latimeridae) Estuarine Crocodiles, Sea Turtles, Sea Snakes, and Marine Mammals. K. E. Capenter \& V. H. Niem Editors. FAO of the United Nations: 216 pp.

Biushing, E. R. 1994. Population dynamics and biology of mackerel resources (genus Rastrelliger spp., family Scombridae) along the west coast of Sabah, Malaysia. In Awaluddin, A., M. Mokhtar, \& S. Mustafa. Marine Fisheries of Sabah. UKM. 1990-1995. Fac. of Science and Nat. Res. Univ. Kebangsaan Malaysia \& Ko-Nelayan: p .34-68.

Collette, B. B. \& C. E. Nauen. 1983. FAO Species Catalogue. Vol.2. Scombrids of the World. An Annotated and Illustrated Catalogue of Tunas, 
Mackerels, Bonitos, and Related Species Known to Date. FAO Fish. Synop. (125) 2: 137pp.

De Beaufort, L. F. \& W. M. Chapman. 1951. The Fishes of Indo-Australian Archipelago. IX. Percomorphi. E. J. Brill. Leiden: 484 pp.

Longhurts, A. R. \& D. Pauly. 1987. The Ecology of Tropical Ocean. Academic Press. Inc. ICLARM Contribution No.387: 407 pp.

Merta, I. G. S. 1993. Perkembangan Perikanan Pelagis Kecil Terutama Perikanan Kembung di Kalimantan Barat. Interim Report Balai Penelitian Perikanan Laut. 21 pp.

Merta, I. G. S. 1994. Status perikanan kembung perempuan (Rastrelliger brachyosoma) di Kalimantan Barat. Jurnal Penelitian Perikanan Laut. 79: p. 61-73.
Sudjastani, T. 1974. Dinamika Populasi Ikan Kembung di Laut Jawa. Lembaga Penelitian Perikanan Laut. 1/74: p. 30-64.

Sudjastani. 1976. The Species of Rastrelliger in the Java Sea, their Taxonomy, and Morphometry (Perciformes, Scombridae). Reprinted from Marine Research in Indonesia. No.16. National Institute of Sciences. Indonesian Institute of Science. Jakarta. Indonesia. p. 1-29.

Yamaji, I. 1976. Illustration of Marine Plankton of Japan. Hotkusha Publishing Co. Ltd. Japan. 538 pp. 